\title{
Sporophytes in the genus Saitobryum (Pottiaceae, Bryophyta)
}

\section{Esporofitos en el género Saitobryum (Pottiaceae, Bryophyta)}

\author{
Guillermo M. SuÁrez ${ }^{1}$, María M. Schiavone ${ }^{1}$ \& Richard H. Zander ${ }^{2}$ \\ ${ }^{1}$ Fundación Miguel Lillo, Miguel Lillo 251, San Miguel de Tucumán, Tucumán, Argentina. CONICET. \\ ${ }^{2}$ Missouri Botanical Garden, PO Box 299, St. Louis, MO 63166-0299 USA. \\ suarezgm@csnat.unt.edu.ar \\ RESUMEN
}

\begin{abstract}
Se presenta una detallada descripción de Saitobryum lorentzii para Argentina, la que representa una enmienda de la diagnosis original de la especie y el género. Los caracteres esporofíticos son ilustrados por primera vez a través de fotomicrografías. Saitobryum lorentzii se diferencia por sus hojas ovadas a obovadas, la zona central de la lámina media pluripapilosa, cápsula púrpura, cilíndrica, sin peristoma y el cuello poco diferenciado.
\end{abstract}

In the course of a project evaluating bryophyte diversity in Argentina grasslands between $20^{\circ}$ and $30^{\circ} \mathrm{S}$ latitude some collected specimens were identified as Saitobryum lorentzii (Müll.Hal.) Ochyra, a species of Pottiaceae with a mainly Andean distribution. Originally collected in Tucumán, Argentina, this species has also been recorded for Mexico, Peru, Ecuador (Ochyra 1999), Bolivia (Cano et al. 2008) and Chile (Cano 2003) (Fig. 1), however, its sporophyte is only known from a few traits given in the original description.

Saitobryum lorentzii has been collected at $2798 \mathrm{~m}$ in high elevation grasslands in the province of Tucumán, forming an extensive copper-red turf on a sandy slope, exposed to the sun, next to a road. This area is similar to the "La Ciénaga", which is the type locality of S. lorentzii (where some sterile samples were also found). Almost all plants of the collection were fertile, forming an almost pure low turf, mixed with a few plants of Didymodon australasiae (Hook. \& Grev.) R.H.Zander (also fertile) and D. umbrosus (Müll.Hal.) R.H.Zander. The collection area is dominated by Festuca orthophylla Pilg. (Poaceae), Lobivia bruchii Britton \& Rose (Cactaceae), a succulent plant endemic to the province of Tucumán, and a wide variety of mosses covering nearby boulders of volcanic origin.

This paper presents a detailed description and illustration of the species and its sporophytes and represents an emended description of the species and genus. A distribution map of the species in the Americas is presented.
Saitobryum lorentzii (Müll.Hal.) Ochyra, Fragm. Florist. Geobot. 44: 255. 1999 (Figs. 2 \& 3).

Pottia lorentzii Müll.Hal., Linnaea 42: 309. 1879; Stegonia lorentzii (Müll.Hal.) I. Hagen, K. Norsk. Vid. Selsk. Skrift. 1928 (3): 28. 1929. Type citation: Argentina Tucumanensis, montibus alpinis inter Siambon et Tafi; Cienaga in Sierra de Tucumán. Lectotype (vide Ochyra 1999: p. 255): “Argentina, Siambon, Tafí”(S-Kindberg; isolectotypes: $\mathrm{H}-\mathrm{Br}$ !, S).

Globulina peruviana R.S.Williams, Bull. Torrey Bot. Club 43: 325. 1916; Globullinella peruviana (R.S. Williams) Steere, J.Wash. Acad. Sci. 36: 222. 1946; Saitoa peruviana (R.S.Williams) R.H.Zander, Phytologia 65: 431. 1989; Saitoella peruviana (R.S. Williams) Menzel, J.Hattori Bot. Lab. 71: 240. 1992; Saitobryum peruvianum (R.S.Williams) R.H.Zander, The Bryologist 100 (4): 520. 1997. Type citation: Perú. Araranca, South side of Roya Pass, about 4,100 m., April, 1915, Cook \& Gilbert 177a (Lectotype, selected here: NY!). First synonymized by Ochyra \& LewisSmith (1996: 986).

Description. Plants small, reddish brown to deep red, growing in dense, low turfs. Stem not or occasionally branched, 2.0-3.5 $\mathrm{mm}$ long, transverse section rounded, central strand present, hyalodermis and sclerodermis absent; axillary hairs hyaline, 77-165 $\mu \mathrm{m}$ long, 3-4 cells in length, the distal cell clavate, sparsely radiculose. Leaves densely imbricate when dry, slightly extended 
when moist, suborbicular to widely ovate, $1.0-1.2 \mathrm{~mm}$, basal leaves smaller, $0.5-0.8 \mathrm{~mm}$, concave, apex rounded to slightly emarginate, margin crenulate in the upper half by projecting cell walls, strongly colored by $10-12$ rows of subrectangular to subrhomboidal cells, walls thickened, recurved in upper $2 / 3$ of lamina, costa ending 3-7 cells before the apex, thickest in the upper half of the lamina, dorsally with 4-6 rows of long, thick-walled, fusiform cells, and ventrally with 4-6 rows of short-rectangular to quadrate cells toward the base, with thinner walls than the ridges, and papillose in 1/3 upper lamina 2-3 rows of shortrectangular cells, costal transverse section semicircular and ventrally convex, stereid band present dorsally, strong, elliptical, ventral epidermis strongly differentiated, made up of thin-walled, papillose cells, dorsal epidermis absent or present, guide cells absent, hydroid strand absent; upper laminal cells subquadrate to subrectangular, 12.5-18.7 x 7.5-12.5 $\mu \mathrm{m}$, papillae restricted to a small central portion of the lamina, 4-6 per cell, basal cells quadrate to shortrectangular, 12.5-37 x 12.5-18 $\mu \mathrm{m}$, walls thin. Dioicous. Male plants with perigonial leaves little differentiated from vegetative, antheridia large, filiform paraphyses abundant, brown, with 4-7 short distal cells. Perichaetia terminal or at the ends of short branches, with 7-8 archegonia without paraphyses; inner perichaetial leaves sheathing the vaginula and the basal portion of seta, oblong, slightly longer than vegetative leaves. Seta erect to slightly curved, yellowish, 3.0-4.5 mm long, twisted clockwise, flat in cross section with epidermis strongly cutinized, central strand reduced. Capsule purple, cylindrical, 1.0-1.2 mm long, with persistent annulus with 1 row of vesiculose cells, eperistomate, neck poorly differentiated; exothecial cells long-rectangular, firm-walled, 50-125 x 12-22 $\mu \mathrm{m}$; stomata 7-9 per capsule, semicryptopore, operculum short apiculate, slightly curved to the right. Calyptra cucullate, smooth. Spores spherical, brown, papillose, $12.5-15(-21)$ in diameter. Laminal $\mathrm{KOH}$ color reaction red.

Observations I. The male plants have 2-3 lateral inflorescences. The female plants are perennial; the apical cell continues growing so that sporophytes appear lateral at the base of the stems. Stems branch at the apex and each branch is apparently potentially fertile.

The Mexican material of $S$. lorentzii has obovate, plane leaves, whereas in Argentine material has ovate leaves, either plane or weakly and broadly recurved at the margins. The Peruvian material is intermediate, with short-ovate to short-elliptical leaves, and margins plane.

The recently described Globulinella halloyi Schiavone \& Suárez from Argentina is similar to Saitobryum in the concave, ovate to rounded leaf shape and rather thick costa ending before the apex. However, S. lorentzii differs in the upper lamina bordered by many rows of rhomboidal, thickwalled cells, upper laminal cells papillose, and costa lacking

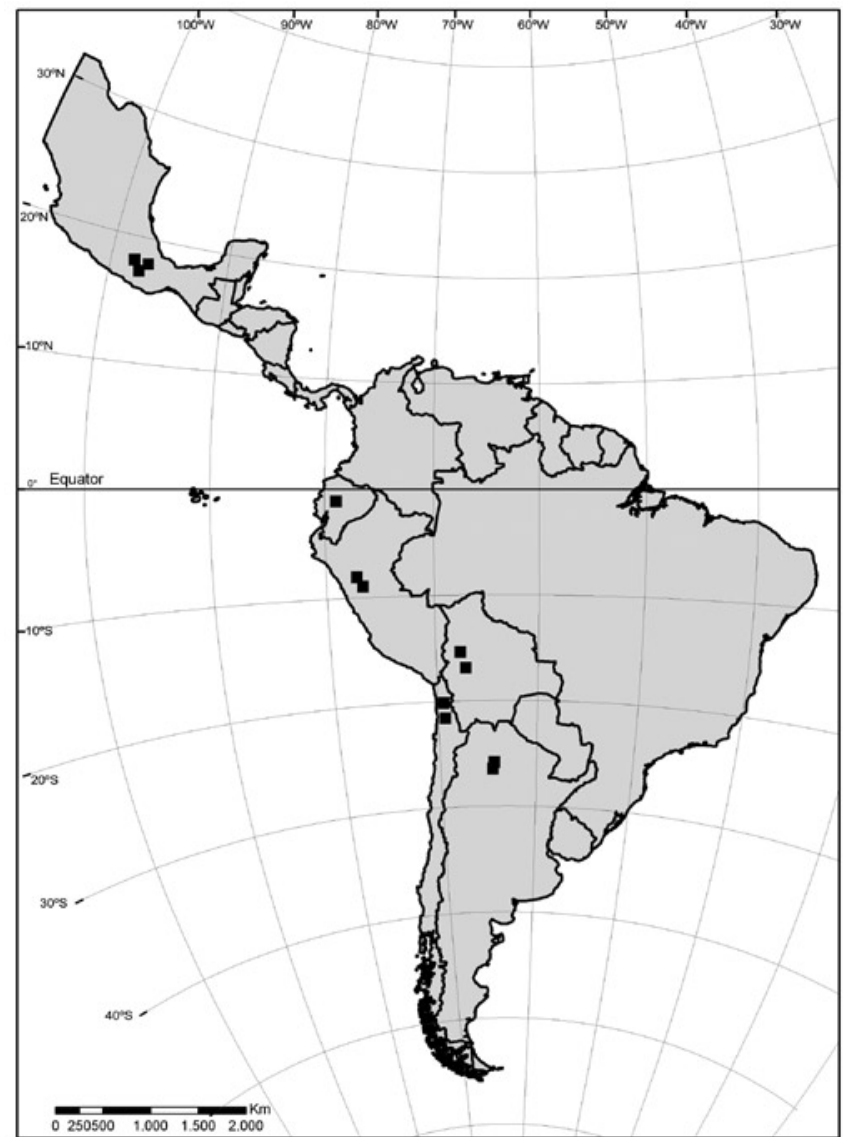

Figure 1. Known distribution of Saitobryum lorentzii.

FIgURA 1. Distribución conocida de Saitobryum lorentzii.

guide cells and red $\mathrm{KOH}$ color reaction. Also, G. halloyi has a ventrally and dorsally toothed costa, and propagula are usually present (Schiavone \& Suárez 2009).

Observations II. H. A. Crum (1994) described Globulinela peruviana (=Saitobryum peruvianum) and he wrote "inflorescences and sporophytes unknown", although, he provides an illustration of the plant with its sporophyte (Fig. 269 a-e). This figure corresponds, however, to Globulinella globifera and not G. peruviana (Fig. 269 f-j).

Specimens examined. ARGENTINA. Tucumán. Depto. Tafí del Valle, Carapunco, 26 $466^{\prime} 33$ 'S, 6543'45"W, 2798 m, 07/06/2009, G. Suárez 610 (LIL, MO); 14/06/2009, M. Schiavone \& G. Suárez 3410 (KRAM, LIL); La Ciénaga, inter Tafí del Valle and El Siambón, 2646'24" S, 65³9’02”W, 2600 m, 12/09/2009, G. Suárez 652 (Topotype: LIL). 

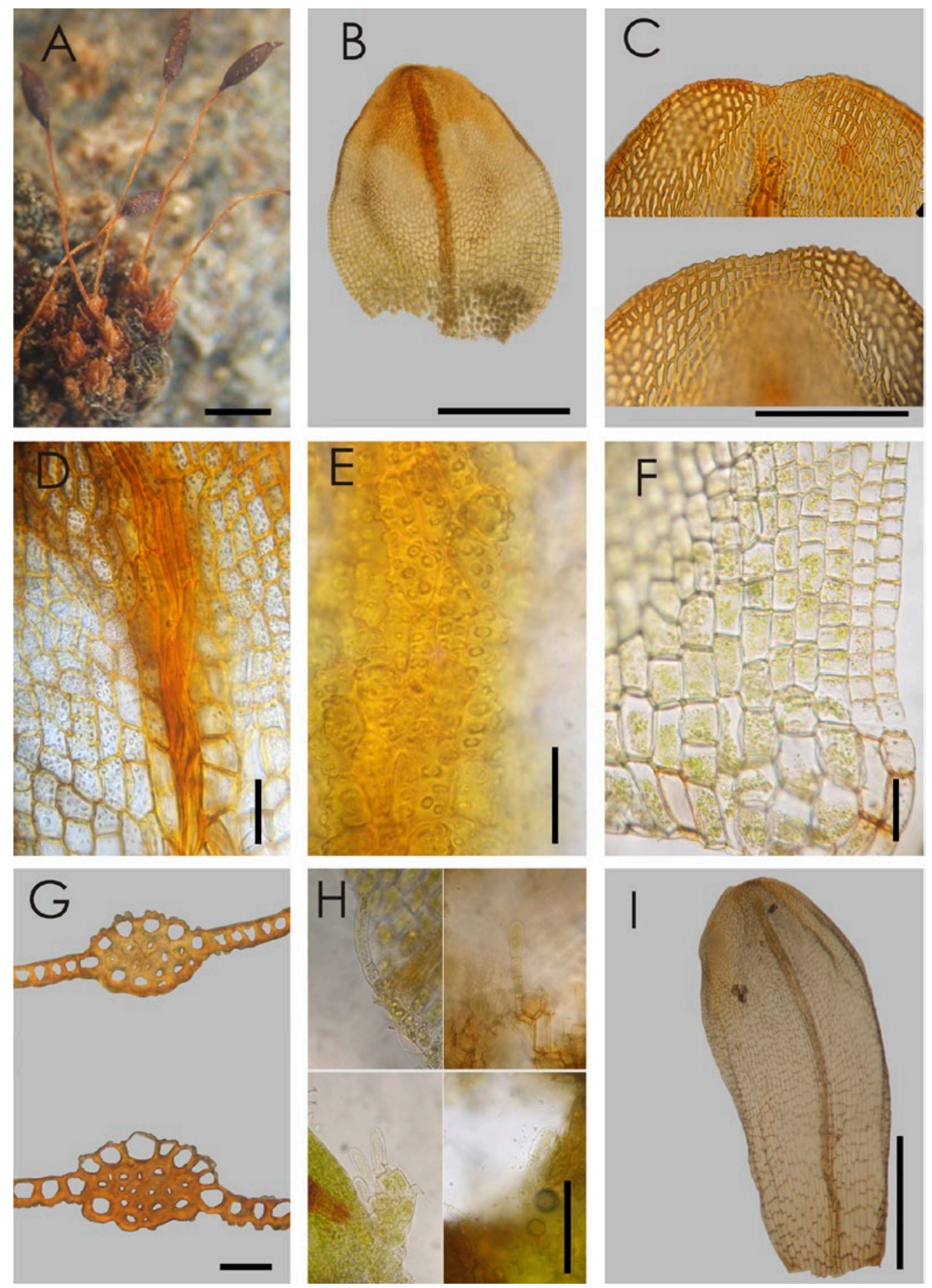

Figure 2. Saitobryum lorentzii. A- Habit dry, B- Leaf, C- Two apex, D- Upper laminal cells, E- Costa (superficial dorsal view), F- Basal laminal cells, G- Transverse section of the costa below midleaf, H- Axillary hairs, I- Perichaetial leaf. Scale bars: A= $1 \mathrm{~mm}$; B, I= 0.5 $\mathrm{mm} ; \mathrm{C}=0,25 \mathrm{~mm} ; \mathrm{D}, \mathrm{E}, \mathrm{F}, \mathrm{G}=18 \mu \mathrm{m} ; \mathrm{H}=100 \mu \mathrm{m}$. (G. Suárez $610 \mathrm{LIL}$ ).

Figura 2. Saitobryum lorentzii. A- Hábito al estado seco, B- Hoja, C- Apices, D- Células de la lámina (superiores), E- Costa (vista superficial dorsal), F- Células basales, G- Sección transversal de la costa, H- Pelos axilares, I- Hoja periquecial. Escalas: A=1 mm; B, $\mathrm{I}=0,5 \mathrm{~mm} ; \mathrm{C}=0,25 \mathrm{~mm} ; \mathrm{D}, \mathrm{E}, \mathrm{F}, \mathrm{G}=18 \mu \mathrm{m} ; \mathrm{H}=100 \mu \mathrm{m}$. (G. Suárez $610 \mathrm{LIL}$ ). 

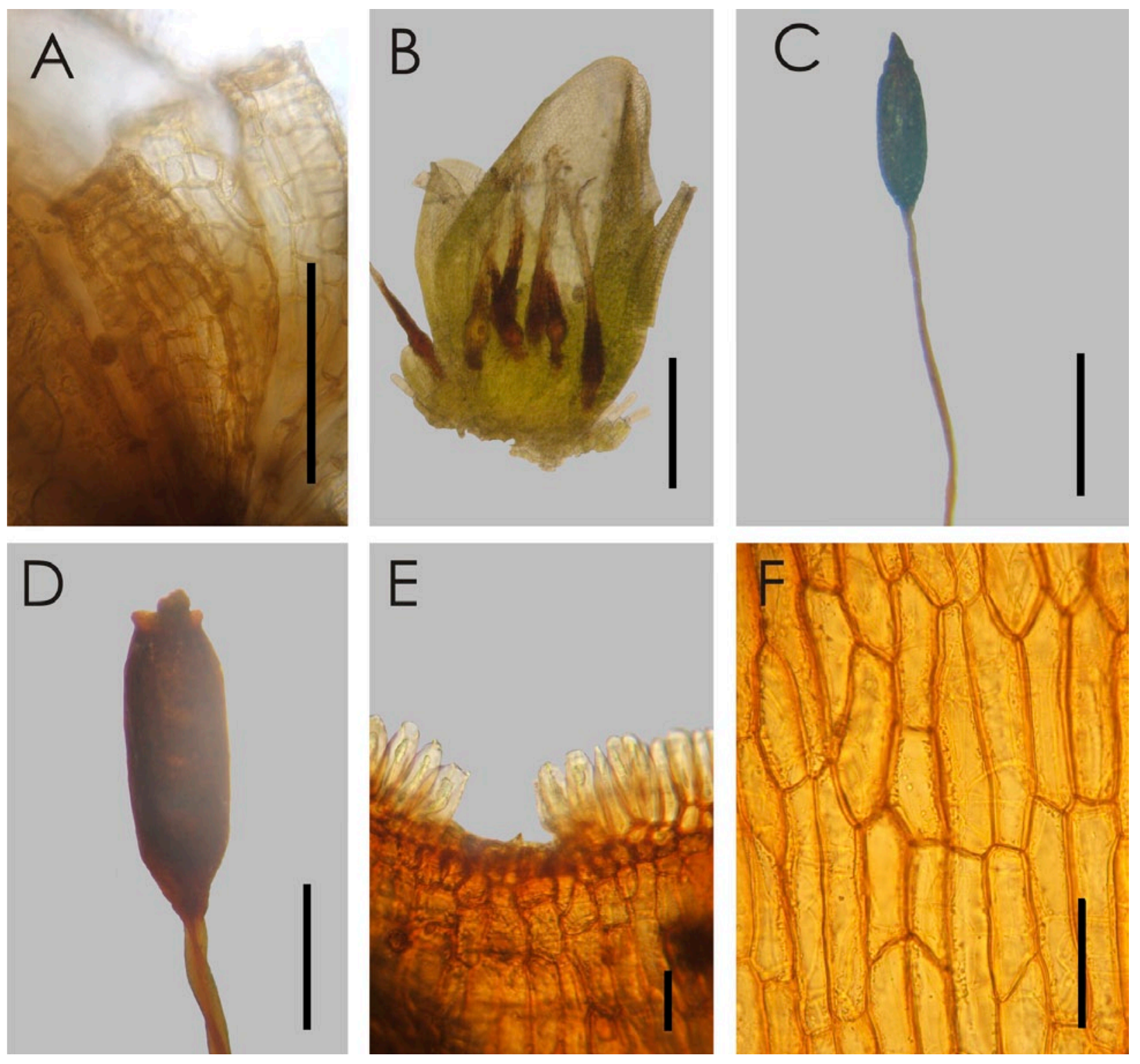

FIgURE 3. Saitobryum lorentzii. A- Antheridia, B- Archegonia, C- Operculated capsule, D- Capsule without opercula, E- Annulus, FExothecial cells. Scale bars: A= $0.25 \mathrm{~mm} ; \mathrm{B}, \mathrm{D}=0.5 \mathrm{~mm} ; \mathrm{C}=1 \mathrm{~mm} ; \mathrm{E}, \mathrm{F}=50 \mu \mathrm{m}$. (M. Schiavone \& G. Suárez 3410 LIL).

Figura 3. Saitobryum lorentzii. A- Anteridio, B- Arquegonio, C- Cápsula con opérculo, D- Cápsula sin opérculo, E- Anillo, F- Células exoteciales. Escales: $A=0,25 \mathrm{~mm} ; \mathrm{B}, \mathrm{D}=0,5 \mathrm{~mm} ; \mathrm{C}=1 \mathrm{~mm} ; \mathrm{E}, \mathrm{F}=50 \mu \mathrm{m}$. (M. Schiavone \& G. Suárez 3410 LIL). 


\section{ACKNOWLEDGEMENTS}

We thank Juan Larraín and María Cano for comments and suggestions on the manuscript. This work was supported by CIUNT.

\section{LITERATURE CITED}

CAnO, M.J. 2003. New records and range extensions of some mosses in tropical areas of Chile. Tropical Bryology 24: 15-20.

CAno, M.J., J.A. JimÉnez, S.P. Churchill \& J. GuerRa. 2008. New records of Pottiaceae (Bryophyta) for South America. Cryptogamie, Bryologie 29(2): 183-191.
Crum, H.A. 1994. Globulinella. In: A.J. Sharp, H. Crum \& P. Eckel (eds.), The Moss Flora of Mexico. Memories of New York Botanical Garden 69: 359-362.

OchYrA, R. 1999. New combinations in Neotropical mosses. Fragmenta Floristica et Geobotanica 44(2): 255-259.

Ochyra, R. \& R.I. Lewis-Smith. 1996. Antipodal mosses: VI. Stegonia latifolia (Musci, Pottiaceae) in the Antartic. Fragmenta Floristica et Geobotanica 41(2): 985-994.

Schiavone, M.M. \& G.M. SuÁrez. 2009. Globulinella halloyi (Pottiaceae), a new species from Argentina. The Bryologist 112(3): 584-588.

Zander, R.H. 1993. Genera of the Pottiaceae: Mosses of harsh environments. Bulletin of the Buffalo Society of Natural Sciences 32: 1-378.

Recibido: 13.11 .09

Aceptado: 18.03.10 